\title{
The Effect of Fundamental Determinants on
}

\section{Voluntary Disclosure of Financial and Nonfinancial Information: the Case of Internet Reporting on the Tehran Stock Exchange}

\author{
Abdolreza Ghasempour. Universiti Utara Malaysia. Malaysia. reza52_gh@yahoo.com \\ Mohd Atef bin Md Yusof. Universiti Utara Malaysia. Malaysia.
}

\begin{abstract}
The recent tendency of businesses toward voluntary disclosure has improved the quality of financial reporting. High-quality financial reporting helps users of financial information trust the business, and thus creates value for the business. Also, during the last decade there has been a profound revolution in information technology as a result of the Internet, and obviously accounting has been directly affected by this change. The present study divides voluntary disclosure into two groups of financial and non-financial information and investigates the effects of fundamentals on voluntary disclosure by businesses. The population is composed of 65 companies listed on the Tehran Stock Exchange from 2005 to 2012. The hypothesis testing results show that firm size, business complexity, earnings volatility, and firm value had a significant and positive impact on voluntary disclosure, whereas financial leverage had a significant and negative impact on voluntary disclosure, while no relationship was observed between voluntary disclosure and financial performance.
\end{abstract}

Key words: Voluntary disclosure, Fundamental variables, Financial reporting, Financial performance, Internet Reporting

\section{INTRODUCTION}

With the development of privatization and economic growth, shareholding has grown to become a public trend. The increasing number of shareholders and 
active institutions in the financial sector, including but not limited to investment companies, rating agencies, mutual funds, brokerage firms, and investment advisory firms, necessitates broad studies on finance and accounting. Due to the sudden changes in the stock market structure, policy makers need to enact laws and regulations for companies to minimize the possibility of misrepresentation and encourage disclosure of information. These policies prepare companies for global stock exchange markets.

Information published on a web site on the Tehran stock exchange listed firms is immediately available anywhere in the world at the same time. This contrasts with print-based information, which could take from a few minutes (e.g., a fax of a quarterly report) to many days for a mailed copy of a printed annual report. The AICPA's Special Committee on Financial Reporting found that users wish to know about critical transactions and events as soon as possible. Speedy release of such information can be made through releases on the corporate Web sites. Further, the web site can readily host complete archives of corporate press releases as well as in-depth background on products and services.

The Web provides a form of dissemination that can provide a flexible format to present forward-looking information. The recent webcasting by a number of corporations of earnings calls and analysts briefings shows how the Web can provide a vehicle for forecasts. At the same time, the Web can reduce some of the inherent risks to corporations by providing forecast information, for example, making explicit use of safe-harbor provisions. Among the most important areas are studies investigating information disclosure by companies as well as investor behavior, attempting to identify the fundamentals underlying different investor decision-making under equal circumstances. Scholars, analyzers, and empiricists (Verrecchia, 1983; Hughes, 2000) have concerned themselves with the incentives of companies for voluntary disclosure. In recent decades numerous researchers (Verrecchia, 1983, 2001; Hughes, 2000) have sought to identify variables defining the behavior of shareholders and other stakeholders. The present study adds further to the mentioned studies.

Verrecchia (2001) maintained that global investors and creditors base their decisions on the information reported in different economic, financial, and nonfinancial reports provided by stock exchange listed companies. Prior to decision-making concerning investment on a specific share, investors and 
creditors also take into account profitability, financial particulars, and nonfinancial particulars including staff information, Board Members' salary and benefits, and internal stock transfers. Therefore, voluntary disclosure, undertaken by many companies listed on the world's most credible stock exchange markets, is a logical development of basic information disclosure in annual financial reports, necessarily reflecting the information pertaining to the economic realities of a company in a meaningful, transparent, and comparable manner (Ettredge, et al. 2002). In Iran, with the enactment of the Internal Auditing By-Law as well as the By-Law of Corporate Governance the first steps have been taken toward voluntary disclosure on the part of companies. However, traditional and not so comprehensive and detailed disclosure of general information in the reports of Board of Directors or exclusive websites of companies, and very little in notes accompanying financial reports are still the only sources for optional and voluntary disclosure of information by Iranian companies.

As the supply of Web-based financial information increases, investor demand for Web-based financial reporting is also increasing. There are now many millions of individual investors throughout the world who use the Web to research corporations as well as to make direct equity investments on both local and foreign bourses. Professional investors and managers use the Web to supplement proprietary databases (Ettredge et al., 2002). Studies on voluntary disclosure have been conducted in many developed countries (Debreceny et al., 2001). In order to protect the interests of public investors and the other parties in the market, a legal and efficient system of disclosure needs to be devised. With the development of securities market in many developed countries including the US (10-K Act) and East Asian countries such as China, a large amount of legal information concerning public disclosure of information has been published by the listed companies on Stock Exchange Markets for public consideration. Yet, scholars, analysts, and empiricists have regrettably not considered specific laws focusing on the incentives of firms for voluntary disclosure. Analytical studies indicate how competition influences disclosure levels (Verrecchia, 1983; Marston and Shrives, 1991), and how disclosure is employed as a signal for a firm's value. The present study is specifically concerned with the voluntary disclosure of information on the intellectual capital and knowledge assets in the Tehran Stock Exchange. This approach fills some of the mentioned research gaps and further develops the related literature on a global level. 


\section{THEORETICAL FRAMEWORK AND REVIEW OF THE RELATED LITERATURE}

Disclosure, in its simple and general sense, is defined as transferring and presenting economic information associated with the financial status and performance of firms, whether financial or nonfinancial, quantitative or in other forms. If it is made compulsory through sources of law, this disclosure is referred to as 'mandatory disclosure', and if it is not mandated by any specific regulation, it is considered 'voluntary disclosure'. Furthermore, disclosure implies presenting a minimum amount of information in firm reports, based on which a reasonable evaluation of the firm's relative risks and value can be drawn and which can assist information users in this regard (Owusu-Ansah, 1998).

Both traditional (mainly monetary) and voluntary disclosure (mainly nonmonetary) are efficient sources of information for stakeholders. Empirical studies on voluntary disclosure have a rather long history, commenced by Verrecchia, (1983) and followed by a plethora of complementary studies concerned with investigating the influence of other company features on disclosure, including size, type of stock exchange admission, leverage, and administrative structure (Table 1). Hughes (2000) investigated the Internet corporate reporting practices of Greek listed companies. The aim was twofold: to contribute to the growing literature by examining Internet corporate reporting for a small open European capital market; and to present a model of online dissemination of information by companies of all size in Greece. An Internet Disclosure Index (IDI) of 50 items was constructed, which incorporated content and presentation criteria. A total of 141 corporate websites were screened, and both partial and aggregate scores produced. The scores show that the Greek companies have much work to do in order to enhance the investor relations activities on the Internet. On average, the larger, more established companies have significantly higher levels of disclosure for both financial and non-financial data.

Larrán and Giner (2001) studied the use of the Internet by Spanish companies to disclose financial information. We also discuss the reasons why companies use new technologies to communicate with interested parties and its consequences. The empirical research was based on companies listed on the Madrid Stock Exchange. We analyze not only the information provided, but also the factors that explain the different attitudes of companies toward this vehicle for investors 
relationships. The results show that size is the main factor that explains not only the quantity but also the quality of financial information.

Expenses for the development and collection of detailed information can be rather higher for small companies compared with large corporations. As in large corporations, the mentioned information has already been developed for internal reporting to the administration. Therefore, its disclosure does not incur extra expenses (Owusu-Ansah, 1998). Larrán and Giner (2001) also maintained that production and dissemination of information is a costly activity and larger corporations probably have the required resources and expert staff for the dissemination of financial reports with high disclosure levels and, consequently, higher compliance with the disclosure regulations. It can thus be concluded that disclosure costs per unit are reduced and as a result large corporations disclose higher amounts of information. As noted by Owusu-Ansah (1998) and Stigler (1964), considering the available economic facilities for information production and storage, large corporations are inclined to spend more resources for information production, and disclosure of information is higher in large corporations than small companies. Owusu-Ansah (1998) found that the response to larger negative earnings is mostly obtained through voluntary disclosure by companies. Many studies indicate the effects of disclosure on the cost of capital (Botosan, 1997) and the cost of debt (Sengupta, 1998). There is also much research on corporate governance and disclosure (Chtourou et al., 2001; Peansell et al., 2001; Xie et al., 2001; Beekes et al., 2002; Klein, 2002; Eng and Mak, 2003). In Iran, it seems there are significant research gaps in this area; few studies have been conducted on the subject under discussion, with each addressing only small portions of voluntary disclosure literature (Foroughi, 2008; Kashanipour and Rahmani, 2009; Sajadi et al., 2009; Bayat et al., 2012). Taking into account different stakeholder groups, the present study attempts to develop further the literature in many aspects nationally and in a few aspects worldwide.

Debreceny et al. (2002) had three objectives: (1) to identify design attributes for Web-based financial reporting; (2) to rank those attributes; and (3) to pilot test the Web as a survey tool. Sixty-one attributes were developed from prior studies. The subjects were the subscribers of the "Double Entries" email newsletter. In terms of completeness, the respondents suggested seven additional attributes. Regarding the second objective, some surprises were found. In terms of 
presentation, the respondents were moderately adverse to downloading files, gave relatively low ratings to "bells and whistles," and preferred hyperlinks and other navigation aids such as tables of content over search and query functions. Regarding the third objective, the response rate was $13.2 \%$, which was at the low end of response rates reported by similar projects.

O'Dwyer (2001 and 2003) investigated first-hand the incentives of directors for social information disclosure in annual reports. The results showed that directors maintain that social pressures necessitate the accountability of companies, and disclosure of information in annual reports is deemed as a gesture of redeeming their legitimacy.

Another study by Ettredge et al., (2001) investigated the influence of governance, corporate governance mechanisms, and firm-specific characteristics on the voluntary disclosure of Shanghai Stock Exchange listed companies. The results indicated that sole proprietorship, existence of an audit committee, firm size, and leverage are significantly related to voluntary disclosure. Their findings, moreover, indicated an understanding of disclosure behavior in state-owned entities during the privatization process in China. This study intends to investigate different governance variables and firm-specific characteristics within the framework of Stakeholder Theory.

Ettredge, et al. (2001) focused on the integrity of Internet Financial Reporting (IFR) by reference to the adequacy of underlying corporate governance procedures. Using a sample of 100 large European companies, a questionnaire survey was used to identify whether or not governance procedures that specifically address the distinguishing features of Web-based financial reporting are used by large companies. The results confirm the trend identified in prior research of increasing Internet usage to replicate paper-based financial information. Responses to the questionnaire also suggest that concerns about the integrity of IFR are justified. Erroneous assumptions and assertions by respondents regarding the security of IFR, in addition to knowledge of work undertaken by external auditors, indicate limited engagement with IFR by management of large European companies.

In Australia, Ashbaugh, Johnstone, and Warfield (1999) utilized Legitimacy Theory to explain the changes in disclosure of environmental reports by enterprises for periods in which authorities, including the government and 
Environmental Protection Organization, emphasized compliance with environmental protection regulations. The results indicated that during the years companies were pressured to comply with environmental protection regulations, their disclosure tended to be more desirable and comprehensive in this regard, as compared with the other years. They also found that regulatory requirements concerning environmental protection compel enterprises to turn to environmental disclosure. It seems that business entities struggle to retain their legitimacy via voluntary disclosure when they have violated a social contract.

Deegan et al. (2002) conducted a study on the methods of social and environmental disclosure employed by Australian companies. The results supported the legitimacy-seeking incentives of directors of socio-environmental information-disclosing companies. In another study, Kashanipoor et al. (2009) investigated the relationship between voluntary disclosure of a company and the number of its non-executive directors. Their sample was composed of 239 companies, and their disclosure checklist listed 71 items. Their results showed that there was not a significant relationship between voluntary disclosure and the percentage of non-executive directors on the Board.

Sajadi et al. (2009) studied the relationship between five nonfinancial characteristics of Tehran Stock Exchange listed companies and the quality of their financial reporting. To measure the financial reporting quality, an index was employed containing 155 items, following Iran Accounting Standards and other disclosure pertaining regulations, to investigate possible relationships between the firm size, type of auditing institute, type of industry, ownership structure, and company age, and financial reporting quality, using models of multiple regression. The results showed that firm size, company age, and type of industry maintained significant positive relationships, while ownership structure had a negative relationship with the financial reporting quality. Moreover, the relationship between type of auditing institute and financial reporting quality was not significant.

In their applied descriptive-survey study, Bayat et al. (2012) investigated the feasibility of social reporting by Tehran Stock Exchange listed companies, collecting the data using questionnaires. They concluded that social reporting is not well-received for a number of reasons: absence of a proper accounting information system, reluctance of directors to disclose company's social costs, 
absence of legal standards, and high costs of developing social reports. They also provided evidence indicating that directors are more inclined to disseminate measures they have taken concerning employee welfare and health, charity, and environmental protection.

\begin{tabular}{|c|c|c|c|c|}
\hline $\begin{array}{c}\text { Financial data } \\
\text { on site }(\%)\end{array}$ & $\begin{array}{l}\text { Corporate web } \\
\text { site }(\%)\end{array}$ & Population & $\begin{array}{c}\text { Data collection } \\
\text { date }\end{array}$ & 50 US \\
\hline $37 \%$ & $65 \%$ & Top 150 Fortune 500 companies & March 1996 & $\begin{array}{c}\text { Louwers, Pasewark and } \\
\text { Typpo (1996) }\end{array}$ \\
\hline $55 \%$ & $69 \%$ & Top 150 Fortune 500 companies & May 1996 & $\begin{array}{l}\text { Petravik and Gillett } \\
\text { (1996) }\end{array}$ \\
\hline$>71 \%$ & $89 \%$ & Top 100 Fortune 500 companies & December 1996 & $\begin{array}{c}\text { Flynn and Gowthorpe } \\
\text { (1997) }\end{array}$ \\
\hline $70 \%$ & $87 \%$ & 290 Non-financial US listed companies & $\begin{array}{c}\text { November } 1997 \text { - } \\
\text { January } 1998\end{array}$ & $\begin{array}{l}\text { Ashbaugh, Johnstone } \\
\text { and Warfield (1999) }\end{array}$ \\
\hline $91 \%$ & $95 \%$ & Top 100 Standard \& Poor companies & January 1998 & $\begin{array}{l}\text { Deller, Stubenrath and } \\
\text { Weber (1999) }\end{array}$ \\
\hline$>80 \%$ & $82 \%$ & $\begin{array}{l}259 \text { AIMR companies plus } 231 \text { Compustat } \\
\text { computer technology and biotechnology } \\
\text { companies }\end{array}$ & May 1998 & $\begin{array}{l}\text { Ettredge, Richardson } \\
\text { and Scholz (2001) }\end{array}$ \\
\hline $93 \%$ & $99 \%$ & Top 100 Fortune 500 companies & January 1999 & FASB (2000) \\
\hline & & & & UK \\
\hline $54 \%$ & $75 \%$ & FT-SE 100 companies & August 1997 & $\begin{array}{l}\text { Hussey, Guiliford and } \\
\text { Lymer (1998) }\end{array}$ \\
\hline $72 \%$ & $85 \%$ & FT-SE 100 companies & January 1998 & $\begin{array}{l}\text { Deller, Stubenrath and } \\
\text { Weber (1999) }\end{array}$ \\
\hline $63 \%$ & $91 \%$ & FT-SE 100 companies & March 1998 & $\begin{array}{l}\text { Hussey, Guiliford and } \\
\text { Lymer (1998) }\end{array}$ \\
\hline $71 \%$ & $74 \%$ & Largest 200 UK companies & July 1998 & $\begin{array}{c}\text { Craven and Marston } \\
\text { (1999) }\end{array}$ \\
\hline & & & & Europe \\
\hline $49 \%$ & $19 \%$ & All Spanish listed companies & July 1998 & $\begin{array}{c}\text { Gowthorpe and Amat } \\
\text { (1999) }\end{array}$ \\
\hline $83 \%$ & $98 \%$ & 60 listed Swedish companies & September 1998 & Hedlin (1999) \\
\hline $71 \%$ & $76 \%$ & Top 100 DAX companies & January 1998 & $\begin{array}{l}\text { Deller, Stubenrath and } \\
\text { Weber (1999) }\end{array}$ \\
\hline $\begin{array}{l}63 \% \\
82 \%\end{array}$ & $\begin{array}{l}72 \% \\
88 \%\end{array}$ & $\begin{array}{c}32 \text { companies listed on the Vienna Stock } \\
\text { Exchange }\end{array}$ & $\begin{array}{l}\text { December } 1997 \\
\text { December } 1998\end{array}$ & $\begin{array}{c}\text { Pirchegger and } \\
\text { Wagenhofer (1999) }\end{array}$ \\
\hline $26 \%$ & $37 \%$ & $\begin{array}{c}94 \text { companies listed on the Irish Stock } \\
\text { Exchange }\end{array}$ & July 1998 & $\begin{array}{c}\text { Brennan and Hourigan } \\
(2000)\end{array}$ \\
\hline $56 \%$ & $67 \%$ & $\begin{array}{l}99 \text { companies listed on the Irish Stock } \\
\text { Exchange }\end{array}$ & July 1999 & $\begin{array}{l}\text { Brennan and Kelly } \\
\text { (2000) }\end{array}$ \\
\hline $94 \%$ & $86 \%$ & 188 AEX companies & July 2000 & Lybaert (2002) \\
\hline $99 \%$ & $100 \%$ & Top 100 DAX companies & July 2000 & $\begin{array}{l}\text { Marston and Polei } \\
(2004)\end{array}$ \\
\hline
\end{tabular}

Table 1. Survey of relevant previous research 
In addition to the above examples and table, many scholars have struggled in recent decades to identify the defining variables in explaining firm behavior on Internet reporting. The present study is an attempt to develop these studies further.

\section{METHODOLOGY}

This is a descriptive-library study in terms of data collection, and an applied study in terms of the objective. Furthermore, as concerns hypothesis testing, the research is classified as correlational, adopting a deductive-inductive approach, and of causal-comparative type. In terms of sampling method, it is a semiempirical study. Initially the population was studied, including Tehran Stock Exchange listed companies who were active from March 2005 to 2012. For mean calculation for some of the variables, the period was extended to include March 2002. Then, the companies lacking the required characteristics were excluded, and the sample was ultimately selected from among the remaining companies. The designated variables were later extracted from different information sources, databases, and financial reports of the sample companies, and, consequently, the hypotheses were tested.

\subsection{Sample and sampling procedure}

The population of the present study was Tehran Stock Exchange listed companies who were active from March 2005 to 2012. Approximately 330 companies have been active on the Tehran Stock Exchange since March 2002. However, for mean calculation of some variables, the period has been extended to include March 2002, adding up to 320 active companies. Tehran Stock Exchange Organization was the research location. The research period was from March 2002 to March 2012. As for hypothesis testing, the companies were selected as sample only if:

1. The company is not in the financial intermediation industry, as the capital structure of these institutes are different;

2. The company has been listed on the Tehran Stock Exchange since March 2002;

3. The company's ticker symbol does not suffer a significant halt (i.e. does not suffer a halt of more than three months on the stock market board);

4. The company's data are available. 
Having considered the above conditions, the population shrank to 182 companies, out of which 65 companies were randomly selected and analyzed as the sample. The pertinent data were investigated for a seven-year period, i.e. a total of 455 observations (year-company) were tested for hypothesis testing.

$$
n \geq \frac{N Z_{\alpha / 2}^{2} \times P(1-P)}{(N-1) \epsilon^{2}+Z_{\frac{\alpha}{2}}^{2} \times P(1-P)}=65
$$

\subsection{Research Hypotheses}

To achieve the objectives, the research hypotheses are addressed in two separate divisions.

\section{Primary Hypotheses:}

A. There is a significant relationship between company fundamentals and voluntary disclosure of financial information;

B. There is a significant relationship between company fundamentals and voluntary disclosure of nonfinancial information.

\section{Secondary Hypotheses Group 1:}

A-1.There is a significant relationship between the company's market value and levels of voluntary disclosure of financial information;

A-2.There is a significant relationship between the firm size and levels of voluntary disclosure of financial information;

A-3.There is a significant relationship between access to growth opportunities and levels of voluntary disclosure of financial information;

A-4. There is a significant relationship between complexity of business and levels of voluntary disclosure of financial information;

A-5.There is a significant relationship between financial performance and levels of voluntary disclosure of financial information;

A-6.There is a significant relationship between earnings volatility and levels of voluntary disclosure of financial information; 


\section{Secondary Hypotheses Group 2:}

B-1.There is a significant relationship between the company's market value and levels of voluntary disclosure of nonfinancial information;

B-2.There is a significant relationship between the firm size and levels of voluntary disclosure of nonfinancial information;

B-3.There is a significant relationship between access to growth opportunities and levels of voluntary disclosure of nonfinancial information;

B-4.There is a significant relationship between complexity of business and levels of voluntary disclosure of nonfinancial information;

B-5.There is a significant relationship between financial performance and levels of voluntary disclosure of nonfinancial information;

B-6.There is a significant relationship between earnings volatility and levels of voluntary disclosure of nonfinancial information;

\subsection{Research variables and how they are calculated}

Research variables are listed below as employed in the first section:

1. Voluntary Disclosure Index (VolDiscT) (Francis et al., 2008, Bayat, 2012): voluntary disclosure is defined as disclosure of information by companies besides what is mandated by Iranian Accounting Standards, including the entire financial and nonfinancial items, not listed on the Adequacy of Disclosure Checklist.

Different studies in the pertinent literature have adopted various criteria and scores for measuring voluntary disclosure: management forecasts, managerial speeches, self-constructed scores, and standard scores constructed by credible rating agencies (Association for Investment Management and Research (AIMR) Scores and Standard \& Poor's (S\&P) Transparency and Disclosure Scores, for instance), to mention a few. The self-constructed score was selected for measuring voluntary disclosure for two reasons: first, Brennan and Hourigan (2000) have stated that self-constructed scores are more trustworthy, and properly measure what they stand for (validity). Self-constructed rating scores are more successful than standard disclosure indices especially in cases where many questions are raised concerning the efficiency of externally designed measuring indices (e.g. whether this rating procedure is capable of properly measuring the changes in disclosure approaches taken by the company). To extract voluntary disclosure 
index, this study employed a weighted disclosure index for measuring the disclosure score of each and every company; a disclosure index was developed to this end, composed of approximately 112 financial and 131 nonfinancial items (Bayat, 2012).

Every individual item was assigned a unique score, depending on the perceived importance and weight and extent of disclosure by the company. These scores were mostly retrieved from the companies' websites and Board reports. Voluntary disclosure index can therefore be defined as:

$$
\operatorname{VolDisc}_{j}=\frac{1}{n_{j}} \sum_{i=1}^{n_{j}} w_{i} d_{i}
$$

In which:

VolDisc $_{\mathrm{j}}$ is the disclosure weight index for the company $\mathrm{j}$, and $w_{i}$ represents the assigned weight to the informational item $\mathrm{i}$, as disclosed by the company $\mathrm{j}$.

2. Access to Growth Opportunities $(\mathrm{M} / \mathrm{B})=$ market/book ratio or price/earnings ratio (P/E) (Lybaert, 2002).

3. Leverage $=$ Total Average Debt/Total Average Assets.

4. Size $=$ natural logarithm of the company's total average stock market value.

5. Complexity: total receivables and inventory/total assets (Badavar, 2009).

6. Firm Value: to calculate Tobin's Q, the model proposed by Marston and Polei was employed. Their proposed index follows:

$$
Q=\frac{M V(\text { Eqity })+B V(\text { Debt })}{B V(\text { Asset })}
$$

The ultimate proposed models for investigating the effects of company fundamentals on voluntary disclosure were extracted as follows:

VolDiscT $=\alpha_{0}+\alpha_{1}$ Fvalue $+\alpha_{2}$ Size $+\alpha_{3} M / B+\alpha_{4}$ Leverage $+\alpha_{5}$ Complexity + $\alpha_{6} \mathrm{ROE}+\alpha_{7} \mathrm{EarnVol}+\psi$

VolDisc $1=\alpha_{0}+\alpha_{1}$ Fvalue $+\alpha_{2}$ Size $+\alpha_{3} M / B+\alpha_{4}$ Leverage $+\alpha_{5}$ Complexity + $\alpha_{6} \mathrm{ROE}+\alpha_{7} \mathrm{EarnVol}+\psi$ 
VolDisc $2=\alpha_{0}+\alpha_{1}$ Fvalue $+\alpha_{2}$ Size $+\alpha_{3} M / B+\alpha_{4}$ Leverage $+\alpha_{5}$ Complexity +

$$
\alpha_{6} \mathrm{ROE}+\alpha_{7} \text { EarnVol }+\psi
$$

\section{RESEARCH FINDINGS}

\subsection{Descriptive Analyses}

Table 2 shows the descriptive statistics of research variables. The values were obtained and analyzed using SPSS, Eviews, Stata, and Excel. Results from analyzing descriptive statistics revealed that the obtained scores for the total voluntary disclosure index fluctuated between 13 and 646. This high dispersion of scores indicates the absence of a unified approach among companies for information disclosure. Mean disclosure index score (VOLDISCT) was 126, with a standard deviation of 105.255. High standard deviation of the obtained scores is probably due to the major difference in firm sizes of companies listed on Tehran Stock Exchange. Furthermore, average obtained scores for secondary voluntary disclosure indices, namely, shareholder value creation (VOLDISC1), customers and products (VOLDISC2), intellectual capital and human resources (VOLDISC3), social and environmental reporting (VOLDISC4), and corporate governance (VOLDISC5), were obtained at 94.598, 14.687, 29,570, 6.744, and 5.798 , respectively. This is indicative of the fact that companies are more inclined to disclose the information pertaining to their financial performance and much less their nonfinancial information, especially that pertaining to their corporate governance and socio-environmental reporting.

\begin{tabular}{|c|c|c|c|c|c|}
\hline Variable & Mean & Median & Max & Min & St. Deviation \\
\hline Business Complexity & 0.474 & 0.4597 & 3.757 & 0.029 & 0.327 \\
\hline Leverage & 0.661 & 0.672 & 1.903 & 0.186 & 0.168 \\
\hline Growth Opportunity (M/B) & 3.840 & 2.092 & 47.566 & 0.104 & 4.960 \\
\hline Size & 12.884 & 12.725 & 16.945 & 9.500 & 1.546 \\
\hline Return on Equity & 0.610 & 0.407 & 5.672 & -1.177 & 0.733 \\
\hline Secondary Disclosure Index (VOLDISC1) & 94.598 & 84.5 & 312 & 0 & 57.446 \\
\hline Secondary Disclosure Index (VOLDISC2) & 14.687 & 12 & 110 & 0 & 13.883 \\
\hline Secondary Disclosure Index (VOLDISC3) & 29.570 & 16 & 260 & 0 & 38.128 \\
\hline Secondary Disclosure Index (VOLDISC4) & 6.744 & 3 & 57 & 0 & 9.624 \\
\hline Secondary Disclosure Index (VOLDISC5) & 5.798 & 3 & 43 & 0 & 6.262 \\
\hline Secondary Disclosure Index (VOLDISCT) & 151.361 & 126 & 646 & 13 & 105.255 \\
\hline
\end{tabular}

Table 2. Descriptive Statistics of Research Variables

Normality Test - since the analyses in this section are conducted using Dynamic Panel Estimator (GMM), data normality is not prioritized. Nevertheless, Jarque- 
Bera and Shapiro-Wilk tests were followed through for data normality, and cases of non-normality were normalized using features of STATA software.

\subsection{Step One: Panel or Mixed Model Identification (F-Limer Test)}

Prior to model estimation, it needs to be identified whether the model is with single or multiple y-intercepts, i.e. whether there is a panel or mixed distribution. F-Limer test was utilized to this end. Results of the mentioned tests for models pertaining to the first theory are presented in Table 3.

Here, the $\mathrm{H}_{0}$ implies non-panel distribution. As shown by the results, except for sub-model 2 (Model2), the models maintain panel distribution. As stated above, panel data have singly y-intercept, while mixed data have multiple y-intercepts.

\begin{tabular}{cccc}
\hline Model & Model T & Model1 & Model2 \\
F-Statistics & 1.728 & 1.861 & 1.169 \\
Prob>F & 0.0013 & 0.0003 & 0.2069 \\
$\chi^{2}$ - statistic & 116.919 & 124.691 & 0.0319 \\
Prob> $\chi^{2}$ & 0.0001 & 0.000 & 86.523 \\
Number of observations & 573 & 573 & 573 \\
\hline Model type & Panel & Panel & Mixed \\
\hline
\end{tabular}

Table 3. Panel or Mixed Model Identification (F-LimerTest)

\subsection{Step Two: Random Effects Test and Hausman Test}

Having determined the type of y-intercept, the next issue to deal with is whether the discussed y-intercepts are fixed or random. From a theoretical point of view, if all the $y$-intercepts of the population are present, the model will be a fixed effect model. However, it should be kept in mind that in the case where the conditions justify random effect estimation theory, a Hausman Test needs to be conducted primarily, and if that rejects, a fixed effect model is the correct procedure. The $\mathrm{H}_{0}$ of Hausman test proved that the model is a random effects model. The important point to be considered here is that the basis of Hausman test is that the test is required to be estimated randomly first, and only then can the Hausman test be conducted. Results from the above tests for the first model are in Table 4.

$\begin{array}{cccc}\text { Model } & \text { Model T } & \text { Model1 } & \text { Model2 } \\ \text { Wald chi2 (7) } & 9.167 & 8.532 & \text { - } \\ \text { Prob> chi2 } & 0.241 & 0.288 & -\end{array}$

Final Result

Random Effects

Random Effects

Table 4. Random Effects and Hausman Tests for the Research Models 
As shown by the results, the main model, as well as sub-model 1, is required to be estimated as the random effects of y-intercepts.

\subsection{Step Three: Heteroscedasticity Test}

One of the problems of a regression model is the Heteroscedasticity of modeling errors imposed by the violation of the hypothesis:

$$
\operatorname{Var}\left(U_{i}\right)=\sigma^{2} I
$$

Such an issue in the regression will cause the OLS estimation results to be no longer efficient. The $\mathrm{H}_{0}$ here is Homoscedasticity.

Generalized least squares were adopted for cases of approved Heteroscedasticity.

\subsection{Step Four: Autocorrelation Test}

Another recurrent problem in a regression model is autocorrelation between the residuals. Autocorrelation is violation of one of the standard assumptions of the regression model (the assumption: $\operatorname{COV}\left(\mathrm{u}_{\mathrm{i}}, \ldots, \mathrm{u}_{\mathrm{j}}\right)=0$ ). Thus, the OLS estimation technique loses the best linear unbiased estimator (BLE) feature, and, as a result, the statistical inference would render unreliable. The autocorrelation problem can exist as first order autoregressive process (AR(1)), higher orders, or moving average process (MA(q)). The $\mathrm{H}_{0}$ here is the absence of autocorrelation. In cases observed with first order autocorrelation, coefficient estimates such as $\operatorname{AR}(1)$ were used to obviate autocorrelation.

\subsection{Step Five: Final Estimate of Regressive Models}

The final model is consequently estimated in the final step subsequent to diagnostics. Results of model estimates are given in Table 5.

As observable from the results depicted in Table 4, the t-statistics pertaining to the variables of firm size and complexity of business have significant and positive relationship with the voluntary disclosure levels of financial and nonfinancial information at the significance level of 0.05 in all the three models. The mentioned statistics for the same variables are 2.958 and 2.746 in the main model respectively. In other words, the results show that larger corporations and companies with higher business complexity are more inclined to disclose their information, probably due to the fact that they wish to assure their shareholders 
that the company's resources are properly managed and administered. The pressures of government, other organizations, and media can also be regarded as contributing factors. The negative coefficient of access to growth opportunities, on the other hand, implies that the company has access to a range of opportunities for possible sales promotion, and is reluctant to disclose further pertinent information to maintain its competitive edge. The t-statistics of this variable is 2.505 in the main model. In contrast, according to Table 4, there is no significant relationship between variables of financial leverage, financial performance (profitability), and earnings volatility and voluntary disclosure, i.e. desirable financial conditions do not necessarily trigger higher information disclosure, and possibly other leverages are the contributing factors in this case.

\begin{tabular}{lrrr}
\hline Model & ModelT & Model1 & Model2 \\
y-intercept & 3.222 & 0.813 \\
& $(9.351) * * *$ & $(9.912) * * *$ & $(1.624)$ \\
Access to growth opportunities & -0.189 & -0.130 & $(-449$ \\
& $(-2.505) * * *$ & $(-1.921)^{* *}$ & $(-3.167) * * *$ \\
Size & 0.135 & 0.097 & 0.291 \\
& $(2.958) * * *$ & $(2.402) * * *$ & 0.183 \\
Financial Leverage & 0.169 & 0.069 & $(1.114)$ \\
& $(1.483)$ & $(0.671)$ & 0.175 \\
Complexity of Business & 0.134 & 0.141 & $(2.665) *$ \\
& $(2.746) * * *$ & 0.037 \\
Financial Performance & 0.012 & $(3.246) * * *$ & $-0.725)$ \\
& $(0.330)$ & 0.009 & $(0.287)$ \\
Earnings Volatility & 0.009 & 0.029 & $(-2.432) * *$ \\
& $(0.267)$ & $0.914)$ & 0.230 \\
Firm Value in the Past Year & 0.014 & 0.111 & $(2.474)$ \\
& $(0.206)$ & $(1.823)$ & 0.202 \\
AR(1) & - & - & $(3.416)$ \\
Adj_R2 & & & 0.098 \\
F & 0.065 & 0.076 & 4.778 \\
Prob>chi2 & 4.660 & 5.238 & 0.000 \\
D.W. & 0.000 & 0.000 & 1.84 \\
Number of Observations & 1.700 & 1.87 & 278 \\
\hline
\end{tabular}

Table 5. Final Estimate of Regressive Models

\section{DISCUSSION AND CONCLUSION}

This study investigated voluntary reporting of companies concerning two divisions of financial and nonfinancial information and analyzed the effects of company fundamentals on such reporting. Results from hypothesis testing showed that the variables of firm size and complexity of business have significant and positive relationship with the voluntary disclosure levels of financial and 
nonfinancial information. This suggests that larger corporations and companies with higher business complexity are more inclined to disclose their information, probably due to the fact that they wish to assure their shareholders of the proper management of the company's resources. Pressures from government, other organizations, and the media can also be regarded as additional contributing factors. The negative coefficient of access to growth opportunities, on the other hand, implies that the company may have access to a range of opportunities for possible sales promotion, and is reluctant to disclose further pertinent information to maintain a competitive edge. In addition, there is no significant relationship between variables of financial leverage, financial performance (profitability), and earnings volatility and voluntary disclosure, i.e. desirable financial conditions do not necessarily trigger higher information disclosure, and possibly other leverages are the contributing factors.

Accordingly, most of the research hypotheses, except for the two variables of financial performance and earnings volatility, are proven at the significance level of 0.05 . The findings of the present study in terms of the majority of the variables are consistent with similar studies conducted in other countries (Skinner, 1994; Botosan, 1997, Sengupta, 1998, Xie et al., 2001, Beekes et al., 2002, Klein 2002).

The results of the present study suggest that in their investment decisions analyzers should take into account voluntary disclosure. It is also suggested that Tehran Stock Market devises incentives for smaller companies to encourage voluntary disclosure further.

\section{REFERENCES}

BADAVAR, N.Y. (2009). "Developing and presenting a model to determine and assess the contributing factors on financial reporting quality in Iran," Ph.D. Dissertation in Accounting, Islamic Azad University, Science and Research Branch, Faculty of Management and Economics.

BAYAT, A. (2012). "The relationship between the levels of voluntary disclosure, the cognitive styles of decision-making, and information asymmetry: according to Stakeholder Theory," Ph.D. Dissertation in Accounting, Islamic Azad University, Science and Research Branch, Faculty of Management and Economics. 
BAYAT, A., HEMMATI, K., KARBASIYAZDI, H. (2012). "The assessment of social reporting on behalf of accepted corporations listed in Tehran Stock Exchange”, Business Intelligence Journal (BIJ), vol.5, n. 2: 214-223.

BEEKES, W., POPE, P., YOUNG, S. (2002): "The link between earnings conservatism and board composition: Evidence from the U.K.", Working Paper, Lancaster University.

BOTOSAN C. (1997): "Disclosure level and the cost of equity capital", The Accounting Review, n.72, 336-52.

CHTOUROU, S.M., BEDARD, J., COURTEAU, L. (2001): "Corporate governance and earnings management". Working Paper, University Laval, Canada.

CRAVEN, B.M., MARSTON, C.L. (1999): "Financial reporting on the Internet by leading UK companies", European Accounting Review, vol. 8, n. 2: 321-333. http://dx.doi.org/10.1080/096381899336069

DEBRECENY, R., GRAY, G.L., MOCK, T.J. (2001): "Financial reporting web sites: what users want in terms of form and content", The International Journal of Digital Accounting Research, vol. 1, n. 1: 1-23.

DEBRECENY, R., GRAY, G.L., RAHMAN, A. (2002): "The determinants of internet financial reporting", Journal of Accounting and Public Policy, vol. 21, n. $4,5: 371$.

DEEGAN, C., RANKIN, M., TOBIN, J. (2002): "An examination of the corporate social and environmental disclosures of BHP from 1983-1997: A test of legitimacy theory", Accounting, Auditing \& Accountability Journal, vol. 15, n. 3: 312-43. http://dx.doi.org/10.1108/09513570210435861

ENG, L.L., MAK, Y.T. (2003): "Corporate governance and voluntary disclosure", Journal of Accounting and Public Policy, vol. 22, n. 4: 325-345. http://dx.doi.org/10.1016/S0278-4254(03)00037-1

ETTREDGE, M., RICHARDSON, V.J., SCHOLZ, S. (2001): "The presentation of financial information at corporate web sites", International Journal of Accounting Information Systems, vol. $\quad 2$ : $149-168$. http://dx.doi.org/10.1016/S1467-0895(00)00017-8 
ETTREDGE, M., RICHARDSON, V.J., SCHOLZ, S. (2002): "Dissemination of information for invertors at corporate web sites", Journal of Accountancy and Public Policy, vol. 21: 357-369.http://dx.doi.org/10.1016/S0278-4254(02)00066-2

ETTREDGE, M., RICHARDSON, V.J., SCHOLZ, S. (2002): “Timely financial reporting at corporate web sites", Communications of the ACM, 2002b, vol. 45, n. 6: 67-71. http://dx.doi.org/10.1145/508448.508450

FOROUGHI, D., MIRSHAMSSHAHSHANI, M., POORHOSSEIN, M. (2008): "Directors' attitude towards disclosure of social information: Stock Market listed companies (2007)", Accounting and Auditing Assessments Journal, vol. 15, n. 52: $55-70$.

FRANCIS, F., NANDA, D., OLSSON, A. (2008): "Voluntary disclosure, earnings quality, and cost of capital", Journal of Accounting Research, vol. 46, n. 1: 53-99. http://dx.doi.org/10.1111/j.1475-679X.2008.00267.x

HEDLIN, P. (1999): "The Internet as a vehicle for investor information; the Swedish case", European Accounting Review, vol. 8, n. 2: 373-381. http://dx.doi.org/10.1080/096381899336104

HUGHES, K. E. (2000). "The value relevance of nonfinancial measures of air pollution in the electric utility industry", The Accounting Review, vol. 5: 209-228. http://dx.doi.org/10.2308/accr.2000.75.2.209

KASHANIPOOR, M.; RAHMANI, A.; PARCHINI (2009). "The relationship between voluntary disclosure and non-executive directors", Accounting and Auditing Assessments Journal, vol. 16, n. 57: 85-100.

KLEIN, A. (2002): "Audit committee, board of director characteristics, and earnings management”, Journal of Accounting and Economics, vol. 33, n. 3: 375400. http://dx.doi.org/10.1016/S0165-4101(02)00059-9

LARRÁN, M., GINER, B. (2001): “The use of the Internet for corporate reporting by Spanish companies", The International Journal of Digital Accounting Research, vol. 2, n. 1: 55-85.

MARSTON, C.L., SHRIVES, P.J. (1991): "The use of disclosure indices in accounting research: a review article", The British Accounting Review, vol. 23, n. 3: 195-210. http://dx.doi.org/10.1016/0890-8389(91)90080-L 
MARSTON, C.L., POLEI, A. (2004): "Corporate reporting on the Internet by German companies", International Journal of Accounting Information Systems, vol. 5: 285-311. http://dx.doi.org/10.1016/j.accinf.2004.02.009

OWUSU-ANSAH, S. (1998): "The impact of corporate attributes on the extent of mandatory disclosure and reporting by listed companies in Zimbabwe", The International Journal of Accounting, vol. 33, n. 5: 605-629. http://dx.doi.org/10.1016/S0020-7063(98)90015-2

O'DWYER, B. (2001): "Managerial perceptions of corporate social disclosure: An Irish story", Accounting, Auditing and Accountability Journal, vol. 15, n. 3: 40636. http://dx.doi.org/10.1108/09513570210435898

O'DWYER, B. (2003): "Conceptions of corporate social responsibility: The nature of managerial capture", Accounting, Auditing \& Accountability Journal, vol. 16: 523-557. http://dx.doi.org/10.1108/09513570310492290

PEASNELL, K.V., POPE P.F., YOUNG S.E. (2001): "The characteristics of firms subject to adverse rulings by the financial reporting review panel", Accounting and Business Research, vol. 31, n. 4: 291-311.

SAJADI, H., MANSOUR Z., A. (2009). "Nonfinancial characteristics effective on financial disclosure quality in Tehran Exchange market listed companies", Accounting and Auditing Assessments Journal, vol. 16, n. 57: 51-68.

SENGUPTA, P. (1998): "Corporate disclosure quality and the cost of debt", The Accounting Review, vol. 73, n. 4: 365-376.

STIGLER, G.J. (1964): “A theory of oligopoly”, Journal of Political Economy, vol. 72: 44-61. http://dx.doi.org/10.1086/258853

VERRECCHIA, R. (1983): "Discretionary disclosure", Journal of Accounting \& Economics, vol. 5, n. 3:179- 194.http://dx.doi.org/10.1016/0165-4101(83)90011-3 VERRECCHIA, R. (2001): "Essays on disclosure", Journal of Accounting and Economics, vol. 32 n. 1-3: 97-180. http://dx.doi.org/10.1016/S01654101(01)00025-8

XIE, B., DAVIDSON, W.N., DADALT, P.J. (2001): "Earnings management and corporate governance: the roles of the board and the audit committee", Working Paper, Southern Illinois University, Carbondale, IL. 